\title{
Do reconhecimento da paternidade espuria, para effeitos de alimentos
}

\author{
Dr: Francisco Morato
}

Vem-nos á consulta si a mãe de filho adulterino tem acção para, em seu nome della, promover o reconhecimento da paternidade, tão sómente para o effeito de prestação de alimentos.

Prohibe o Codigo Civil no art. 358 o reconhecimento dos filhos incestuosos e adulterinos, ao mesmo passo que no art. 405 abranda um pouco a dureza do preceito, permittindo a certificação da paternidade espuria, para o effeito de prestação de alimentos, quer por confissão ou escripto recognitivo do pae, quer por sentença irrecorrivel, não provocada pelo filho.

Prohibe o reconhecimento formalistico e espontaneo para os fins de successão ou direitos de familia em geral, mas admitte o reconhecimento não formalizado e coacto para compellir o pae a prestar alimentos.

E' o mesmo principio que vigorava antes da Codificação, segundo ensina e attesta Teixeira de Freitas no art. 222 e em notas 16 e 18 aos arts. 220 e 222 da Consolidação das Leis Civis.

Mas si é hoje, como era dantes, principio do direito patrio que, para os fins de alimentos, abre-se excepção á regra rigida da irreconhecibilidade dos espurios, quando certificada a paternidade, entre outros casos, por sentença irrecorrivel, não provocada pelo filho, vem a lanço indagar em que hypotheses póde dar-se semelhante sentença. 
Para o sabio auctor da Consolidação isto póde acontecer:

1..$^{\circ}$ quando o filho fôr havido de casamento contrahido de má fé, que venha a ser annullado pelos impedimentos de bigamia ou incesto;

$\left.2 .^{\circ}\right)$ quando se julgar que o filho concebido por mulher casada não tem por pae o marido de sua mãe;

3.०) quando uma sentença, insusceptivel de refórma, tiver por erro de facto ou de direito admittido uma investigação de paternidade, cujo resultado implique uma filiação de coito damnado.

Não ha duvida que nas hypotheses figuradas fóde darse o caso de uma sentença irrecorrivel não provocada pelo filho, fazendo certa a paternidade, isto é, um reconhecimento obliquo ou indirecto, que não era objecto immediato da sentença e do pedido, mas que resultou logica e necessariamente do julgado, por via de consequencia.

Serão, porém, esses os unicos casos da sentença irrecorrivel a que allude o art. 405 do Cod. Civil?

Não será possivel, em face da razão juridica e da systematica do nosso direito, uma acção directa de reconhecimento da paternidade espuria, com o objectivo exclusivo da prestação de alimentos?

Aqui é que bate o ponto.

Pensamos que é possivel fazer-se certa a paternidade espuria por meio de acção propria e directa.

Os principios e a logica judiciaria levam-nos, de modo irresistivel, a esta solução.

Está escripto nas leis e foi sempre pacifico na licção dos grandes interpretes que a obrigação de alimentos, assim entre parentes legitimos como entre illegitimos, toca em primeiro logar ao pae e, na falta delle, á mãe (Cod. Civil, arts. 397 e 504. LAFAyetTe: Direitos de Familia, $\S \S 133 e$ 135).

O pae do espurio, comprovada a paternidade por sentença, confissão ou documento escripto, é obrigado a ali- 
mental-o, forrando a mãe ao cumprimento da obrigação alimenticia.

Si a lei, por evitar escandalo dos descendentes contra os genitores, nega ao filho acção contra o pae para reconhecimento da filiação espuria e consequente prestação de alimentos, não a nega á mãe para pleitear esse reconhecimento e transferir de si para o pae o encargo alimenticio.

O que a lei veda é a acção do filho contra o pae, não é a acção da mãe contra o pae.

A mãe tem direito a não ser chamada a este encargo senão em falta do pae. Ora, a todo direito corresponde uma acção que o assegura, conforme pleonasticamente estatue o art. 75 do Cod. Civil. Logo, cabe-lhe intentar acção, para certificada a paternidade, ser liberada do onus.

Acódem a seu favor todas as condições subjectivas que auctorizam o exercicio da acção (JoÃo MonteIro: Theoria do Processo, $\S \S 18$-21).

Assim prescreve, assim tem de ser entendido, assim deve ser praticado o art. 405 do Cod. Civil.

Nem podia ser de outra maneira, sob pena de se cohonestarem as mais repugnantes crueldades. Uma creança atirada ao desamparo e miseria, filha espuria de um argentario deshumano, não teria a acção protectora do Ministerio Publico. A' mãe abandonada do seductor e entregue á fatalidade da mendicancia não seria licito implorar a justiça social sequer para obter do comparte do seu descaminho alimentos para o fructo do peccado commum.

Estes absurdos chocam naturalmente a sensibilidade dos juristas e legisladores; não estão nem podiam estar nas leis.

Não se oppõe a esta intelligencia e applicação o art. 358 , vedatorio do reconhecimento dos incestuosos e adulterinos. Não se oppõe, não só porque ahi se trata do reconhecimento espontaneo e directo dos paes, sujeito a formalidades solemnes, senão tambem porque, quando o texto implicasse qualquer duvida em cotejo com o do art. 405 (o que 
não acontece), força seria entendel-o restrictamente e não amplial-o além das relações a elle submettidas.

$\mathrm{O}$ art. 358 consagra uma dessas disposições iniquas e judaicas, em que se castiga na innocencia dos filhos o peccado dos paes - patres nostri peccaverunt et nos peccata eorum portamus -, resquicio de um lamentavel e tradicional preconceito das legislações latinas, que nos cumpre apertal-o nas proprias expressões, emquanto não logramos eliminal-o, a exemplo das legislações ingleza, allemã, americana e austriaca.

Em conclusão, tem a mãe de filho adulterino ou incestuoso acção para, em nome proprio, pleitear o reconhecimento da paternidade para o effeito da prestação de alimentos. 